\title{
Employment Trends in St. Louis: 1954-82
}

\author{
G. J. Santoni
}

D

URING the last few years, economic activity has been depressed in both St. Louis and at the national level. ${ }^{x}$ Some observers have argued that St. Louis' economy was particularly sluggish during the recent recession and is recovering at a rate that is lagging behind the national recovery. ${ }^{2}$

The relatively poor economic performance of the St. Louis metropolitan area is alleged to have had important consequences for local employment opportunities. Since it is generally thought that the area's depressed economy was due to the slump in automobile production, many commentators are pinning their projections for a recovery in the labor market on the current expansion in the area's auto industry. ${ }^{3}$ Others have argued that the longer-term prospects for the labor market in the St. Louis metropolitan area depend upon more fundamental forces than those capricious

G. J. Santoni is a senior economist at the Federal Reserve Bank of St Louis. Thomas A. Pollmann provided research assistance.

${ }^{1}$ The St. Louis area is defined to be the St. Louts Standard Metropo:ltan Statistical Area (SMSA), which includes St. Louis City; Franklin, Jefferson, St. Charles and St. Louis countes in Missouri; and Clinton, Madison, Monroe and St. Clair counties in Illinois.

'See St. Louis Post-Dispatch (September 13, 1983). For an exception to this view regarding St. Louis' relatively slow recovery, see Wag. man (1983).

${ }^{3}$ St. Louis Post-Dispatch (September 20, 1983); St. Louis GlobeDemocrat (August 17, 1983); and St. Louis Globe-Democrat (September 19,1983 ).

circumstances that have buffeted the U.S. auto industry in recent years. ${ }^{4}$

This article will describe the current employment mix in the St. Louis labor market, compare the longerrun growth in employment opportunities in St. Lous to other similarly sized metropolitan areas and the nation, and assess the recent past in terms of this longer-run view.

\section{THE 1982 EMPLOYMENT PICTURE IN ST. LOUIS}

Chart 1 presents the 1982 percentage distribution of employment by industrial sector in the St. Louis Standard Metropolitan Statistical Area (SMSA). For comparison, a similar distribution for the United States is also given,

The data in chart 1 suggest that the distributions of employment in St. Louis and in the United States in 1982 were quite similar. In both areas, nonmanufacturing employment amounted to about 80 perm cent of total nonagricultural employment, and manufacturing employment accounted for about 20

\footnotetext{
${ }^{4}$ See Gilbert (1973); Kester (1983).

${ }^{5}$ The numbers are obtained by dividing employment in each sector by total nonagricultural employment and multiplying by 100 .
} 
Chart 1

Percentage Distribution of Employment in 1982: St. Lovis and U.S. ${ }^{11}$

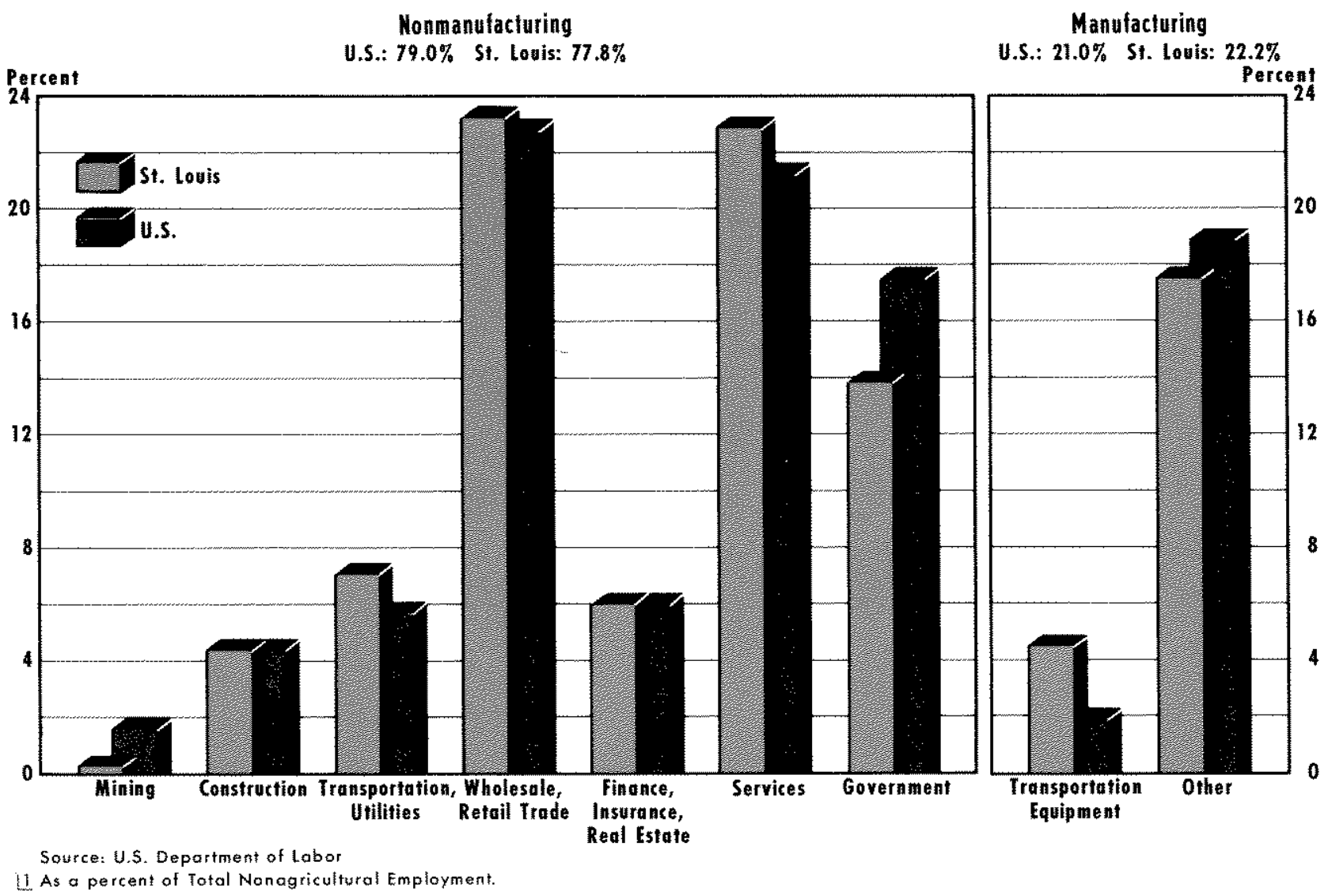

1 As a percent of Total Nonagricutural Employment.

percent. Much of the St. Louis work force (about 45 percent) was employed in wholesale/retail trade and services. The same was true at the national level.

Two differences seem to stand out in chart 1: employment in government and in transportation equipment. Since government employment by geographic sector is related to whether the national capital, state capital or county seat falls within that sector, we might expect govemment employment in the St. Louis SMSA to be less than it is at the national level.

Employment in transportation equipment amounted to 4.6 percent of total nonagricultural employment in the St. Louis SMSA and only 2 percent at the national level. This industry includes motor vehicle, aircraft, ship and boat, and railroad equipment manufacturing.

St. Louis employment in motor vehicle manufacturing, a subcategory of transportation equipment, amounted to about 1 percent of total nonagricultural employment in 1982. At its peak in 1978, St. Louis employment in motor vehicle manufacturing accounted for slightly more than 2.6 percent of total nonagricultural employment. Consequently, although events in the automobile industry may have a larger effect on the local economy than they do on the national economy, the percentage impact on employment locally would appear to be fairly small.

\section{HAS MUCH CHANGED OVER THE PAST 28 VEARS?}

Chart 2 presents the 1954 percentage distribution of employment by sector for St. Louis and the nation. A comparison of charts 1 and 2 reveals several interesting differences. First, there has been a shift in employment from manufacturing to nommanufacturing sectors in both $S t$. Louis and the nation. In St. Louis, manufacturing employment accounted for 38 percent of total nonagricultural employment in 1954 , but only 22 percent in 1982. A similar shift occurred at the national level. In this case, manufacturing employment amounted to about 33 percent of total nonagricultumal employment in 1954, but only 21 percent in 1982. 


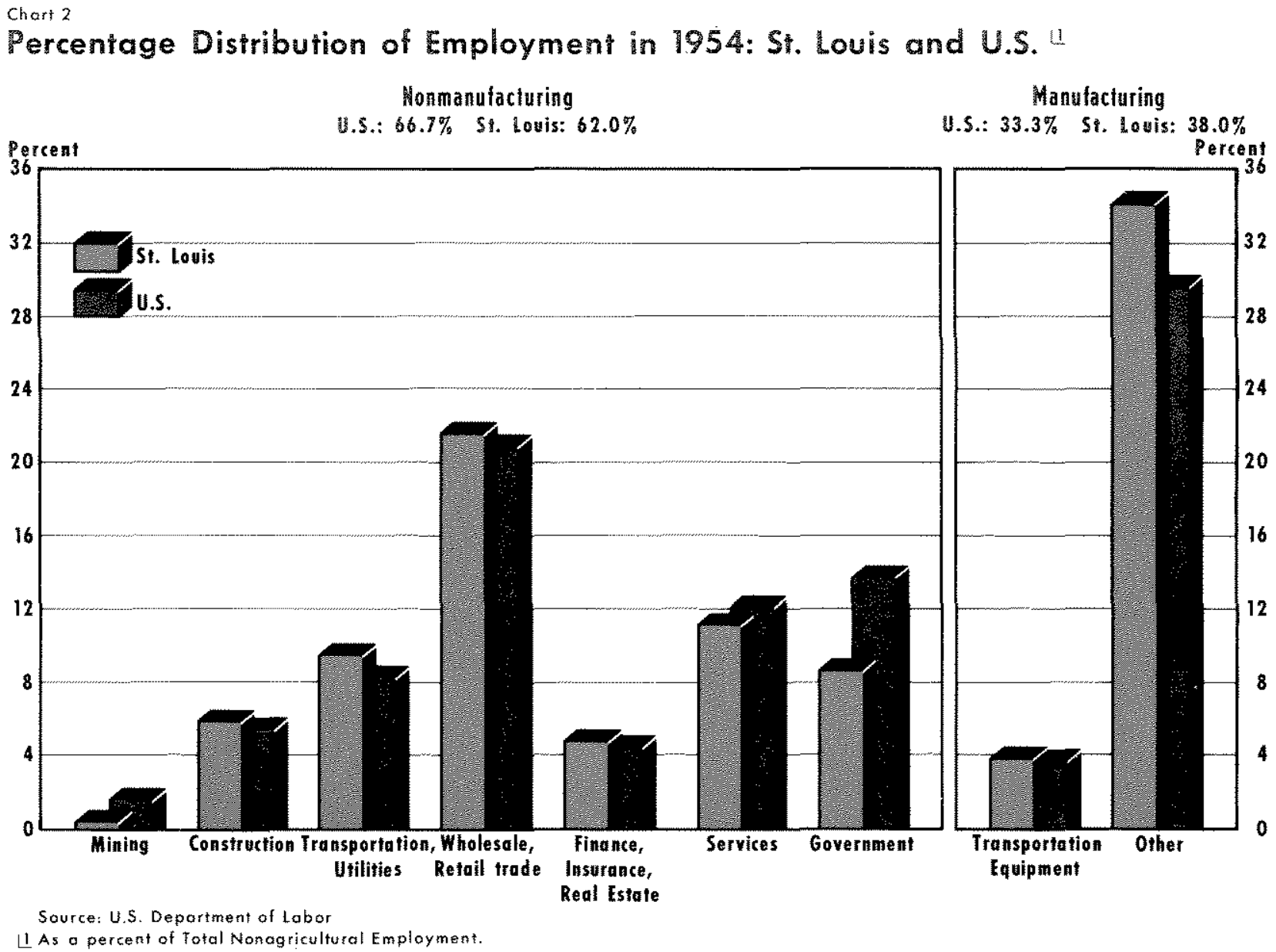

Note also that, in 1954, a greater proportion of St. Louisans were employed in manufacturing when compared with the national employment mix: 38 percent for St. Louis and 33 percent for the nation. By 1982, however, the proportion of St. Louisans employed in manufacturing had fallen to about the national average. ${ }^{6}$

The reduced concentration of employment in the manufacturing industries has been offset by increased employment in govermment and service industries. In the St. Louis area, the proportion of individuals employed in manufacturing fell by 15.8 percentage points between 1954 and 1982 (from 38.0 to 22.2 percent), while the proportion of people employed in govermment and service industries increased by 16.9 percentage points.

${ }^{6}$ There is some ambiguity in these numbers. The definition of the St. Louis SMSA was changed a number of times between 1954 and 1982. The relative decline in manufacturing emptoyment may have been solely due to this redefinition.
Though somewhat smaller in magnitude, a similar shift occured at the national level over this period. As noted earlier, the resulting 1982 employment $\operatorname{mix}$ in the St. Louis area was roughly the same as the nation's.

An exception to this general decline in manufacturing employment in the St. Louis area was employment in transportation equipment manufacturing. This grew from 3.9 percent of St. Louis nonagricultural employment in 1954 to 4.6 percent in 1982; at the national level, however, it fell from 3.7 percent in 1954 to 2.0 percent in 1982.

\section{LONGER-TERM EMPLOYMENT GROWTH IN ST. LOUIS RELATIVE TO TIIE UNITED STATES}

While the current employment mix in St. Louis is about the same as the national mix, the growth rate in local employment has been substantially below that of 


\section{Table 1}

\section{Average Annual Growth Rates in Employment from 1955 to 1982: St. Louis SMSA and United States}

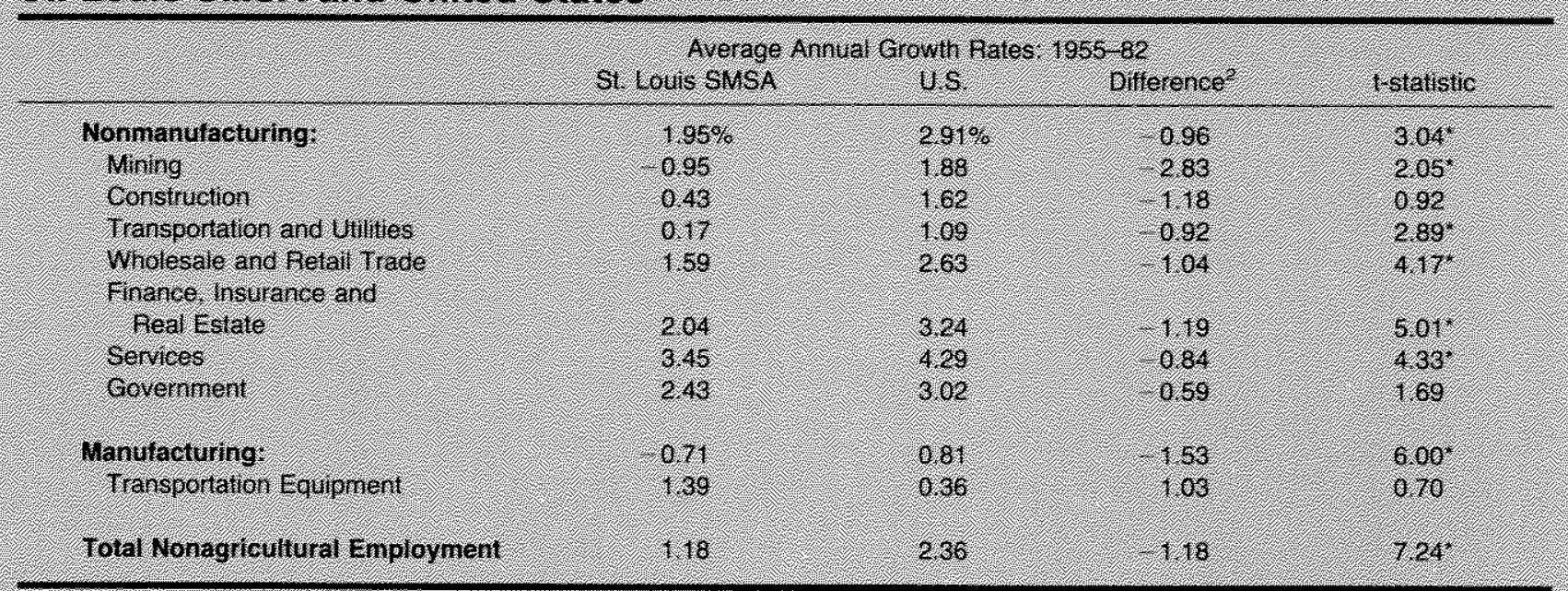

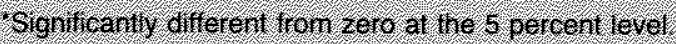

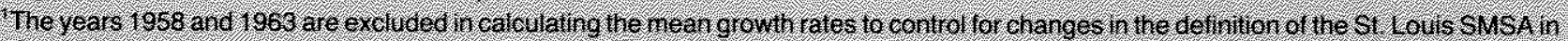
these years.

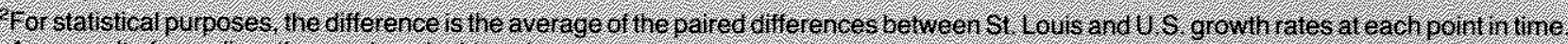

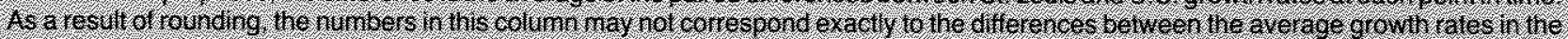
inst two columins.

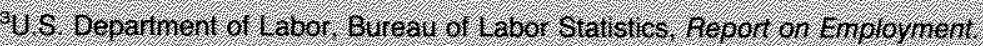

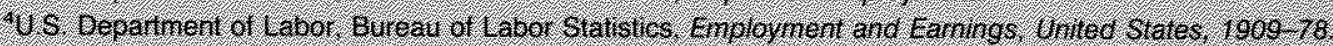

the nation. Table 1 presents the average annual growth rates in nonagricultural employment by industrial sector for the period $1955-82$ for St. Louis and the nation. The annual growth rate in total nonagricultural employment for St. Louis was 1.18 percent; nationally, total nonagricultural employment grew at an annual rate of 2.36 percent. The difference, -1.18 percent, is statistically significant, which means that the observed slower growth for St. Louis is unlikely to be simply an artifact produced by chance variation in the data.

Further, significantly slower growth in St, Louis em* ployment is common to both the manufacturing and nonmanufacturing sectors. Moreover, the slower growth in nonmanufacturing employment is not concentrated in any particular category but seems to be a fairly general phenomenon. The differences between local and national growth rates are statistically insignificant only for construction and government.

Interestingly, the difference between the local and national employment growth rates in the transportation equipment industry is statistically insignificant; the reported difference could have occurred by "chance" or measurement problems even though the actual growth rates were identical. Thus, despite recent events in the auto industry, the transportation equipment industry does not appear to have contrib uted to the generally slower long-run growth rate.

\section{WAS THERE A CHANGE IN EMPLOYMENT TRENDS IN THE LATE 1960s?}

Since some observers have claimed that St. Louis' employment problems became particularly severe beginning in the mid-1960s, tables 2 and 3 split the 195482 period in half at $1968 .^{7}$ By doing so, we can examine the growth rates in total nonagricultural employment during the two subperiods. Table 2 considers the earlier period, 1955-68, and table 3 considers the more

\footnotetext{
7See R. Alton Gilbert, "Employment Growth in St. Louis," pp. 9-15.
} 


\section{Table 2}

\section{Growth Rates in Total Nonagricultural Employment from 1955 to 1968 : St. Louis SMSA and United States}

\begin{tabular}{|c|c|c|c|}
\hline Year & S1 Lous sMSA & 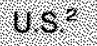 & Difference \\
\hline 1955 & 2.4 & 3.310 & 0.00 \\
\hline & 1.51 & (6.86 & 406 \\
\hline & 0,45 & 0.92 & $(7,37$ \\
\hline 58 & 1128 & 2.94 & 1.66 \\
\hline 59 & 1.95 & 3.72 & 1.777 \\
\hline & 0.94 & 171 & 077 \\
\hline & 236 & 0.35 & .201 \\
\hline 62 & 0.87 & 283 & 1.96 \\
\hline 69 & 4.31 & 197 & 234 \\
\hline & .618 & 284 & 0.34 \\
\hline & 9.92 & 4,17 & 0225 \\
\hline & 5.36 & 5.03 & 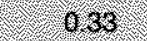 \\
\hline & 222 & 298 & $207 \%$ \\
\hline & 169 & 3.13 & $=144$ \\
\hline Mean & $1,77^{3}$ & $2.80^{\circ}$ & $1.03^{3}$ \\
\hline I statistic & 3.08 & 6.69 & 425 \\
\hline \multicolumn{4}{|c|}{ signifieantly diferent trom zero at the 5 percent level. } \\
\hline \multicolumn{4}{|c|}{ 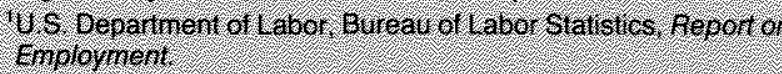 } \\
\hline \multicolumn{4}{|c|}{ 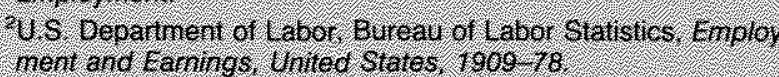 } \\
\hline \multicolumn{4}{|c|}{ 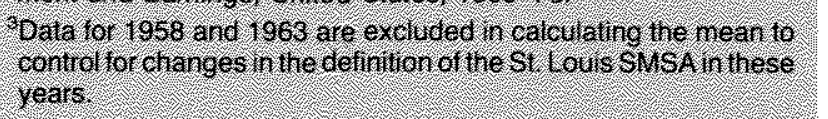 } \\
\hline
\end{tabular}

recent period, 1969-82.8

Before making this comparison, it is important to note that Jefferson County was added to the St. Louis SMSA in 1958 and Franklin County was added in 1963. Notice that the differerice between the growth rates in St. Louis and U.S. employment is positive and large in these two years (see table 2). These observations are excluded from the analysis because including them would bias upward the growth rates for St. Louis in these two years. Excluding the data for 1958 and 1963 , the results in table 2 show a statistically significant difference of -1.03 percent per year between the growth of total nonagricultural employment in the na tion and that for St. Louis. Thus, over this 14-year period, employment growth in St. Louis was substantially slower than that in the rest of the nation.

\footnotetext{
${ }^{8}$ The period begins in 1955 rather than in 1954 because 1954 is our first observation of total employment and this observation is used in calculating the 1955 growth rale.
}

Table 3

\section{Growth Rates in Total Nonagricultural Employment from 1969 to 1982 : St. Louis SMSA and United States}

\begin{tabular}{|c|c|c|c|}
\hline Xear & S1 lowis SUSA & 18 & pitrerence \\
\hline 1969 & $2.19 \%$ & $360 \%$ & 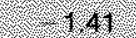 \\
\hline 70 & 0.63 & 068 & .131 \\
\hline 71 & 120 & 0.42 & -1.62 \\
\hline 72 & 027 & 817 & $320^{\circ}$ \\
\hline 73 & 276 & 4,14 & -136 \\
\hline 74 & 1066 & 190 & 1.124 \\
\hline 75 & 250 & 1,70 & 0.80 \\
\hline 76 & 2.4 & 3.12 & 0.98 \\
\hline 77 & 3.84 & 3.62 & 048 \\
\hline 88 & 4,85 & 500 & 065 \\
\hline 79 & 252 & 354 & 102 \\
\hline 80 & 226 & 065 & 291 \\
\hline 61 & 6,6 & 0.63 & 0098 \\
\hline 62 & 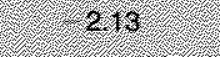 & 178 & 0.40 \\
\hline mean & 867 & 198 & 1,61 \\
\hline Istaisice & 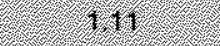 & 345 & 5.98 . \\
\hline
\end{tabular}

Signicantl diferent hom 2 ro a t 1 e o perent level.

- Ues outside the 95 percent contidence intervat which equats 1.31 .17 .6

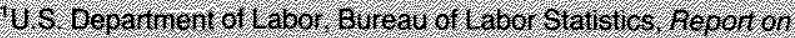
Enoloymen:

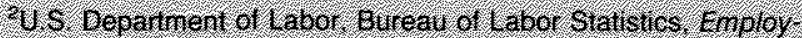

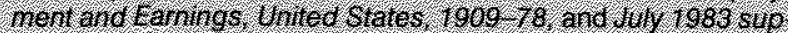
ploment:

The data in table 3 indicate that the slower growth that characterized St. Louis employment during the 1955-68 period has persisted over the more recent period. The second column indicates that the average annual growth rate in total nonagricultural employment for St. Louis, 67 percent, is statistically indistin * guishable from zero over this period. Employment growth at the national level, however, is significantly positive. Just as in the earlier period, more recent employment growth in St. Louis was substantially slower than that for the nation as a whole.

Further, the average difference between the local and national anmual growth rates during the 1969-82 subperiod, -1.31 percent, is statistically indistinguishable from the earlier difference shown in table $2{ }^{9}$ The data in tables 2 and 3 appear to indicate that there has been no substantive change in the differentially slower

\footnotetext{
9 t-statistic $=85$
} 
employment growth in St. Louis between the two subperiods. ${ }^{\text {to }}$

\section{ARE RECESSIONS PARTICULARLY SEVERE IN ST. LOUIS?}

The data in table 3 are also useful in analyzing whether employment in the St. Louis area was particularly hard hit during the recent recession when compared with the rest of the nation. The past recession began in the third quarter of 1981 and ended in the fourth quarter of 1982. The data in table 3 indicate that St. Louis employment growth was below the national average in 1981 and 1982 , but the differences do not appear to be "unusual." As the previous analysis has pointed out, average employment growth locally has been below the national average since 1955 . The difference between local and national growth rates was unusual (in the sense that the difference exceeded a 95 percent confidence interval) only in 1972 . Consequently, the recent recession does not seem to have singled out St. Louis, at least in terms of employment growth.

In fact, recessions generally have not had a differentially severe impact on the local labor market. Recessions occurred in 1970, 1974, 1980, and from the third quarter of 1981 through the fourth quarter of 1982. St. Louis employment growth has not slowed unusually relative to the national average during any of these recessions.

Further, the slow growth in St. Louis employment was not unusually aggravated during the years of substantial reductions in the work forces of the various auto manufacturing plants located in the St. Louis SMSA. The work forces of these plants fell from a 1978 peak of about 27,000 workers to about 9,000 in 1982 . Yet the growth rate in St. Louis employment was not unusually depressed relative to the national average in any of these years.

This evidence suggests that the problem of relatively slow employment growth in St. Louis is neither the result of problems confronting domestic auto manufacturers in recent years nor the result of differential effects of business cycles on the St. Louis labor market. Instead, the slower growth in St. Louis employment when compared with overall employment growth in

\footnotetext{
${ }^{10} \mathrm{Clinton}$ and Monfoe counties in Illinois were added to the St. Louis SMSA in 1970. Due to their relatively small size, however, they do not appear to have significantly distorted the estimated growth rate for 1970.
}

\section{Table 4}

Growth Pates in Total Nonagricultural Employment from 1969 to 1982 . St. Louis SMSA Vs. Average of Comparable SMSAst

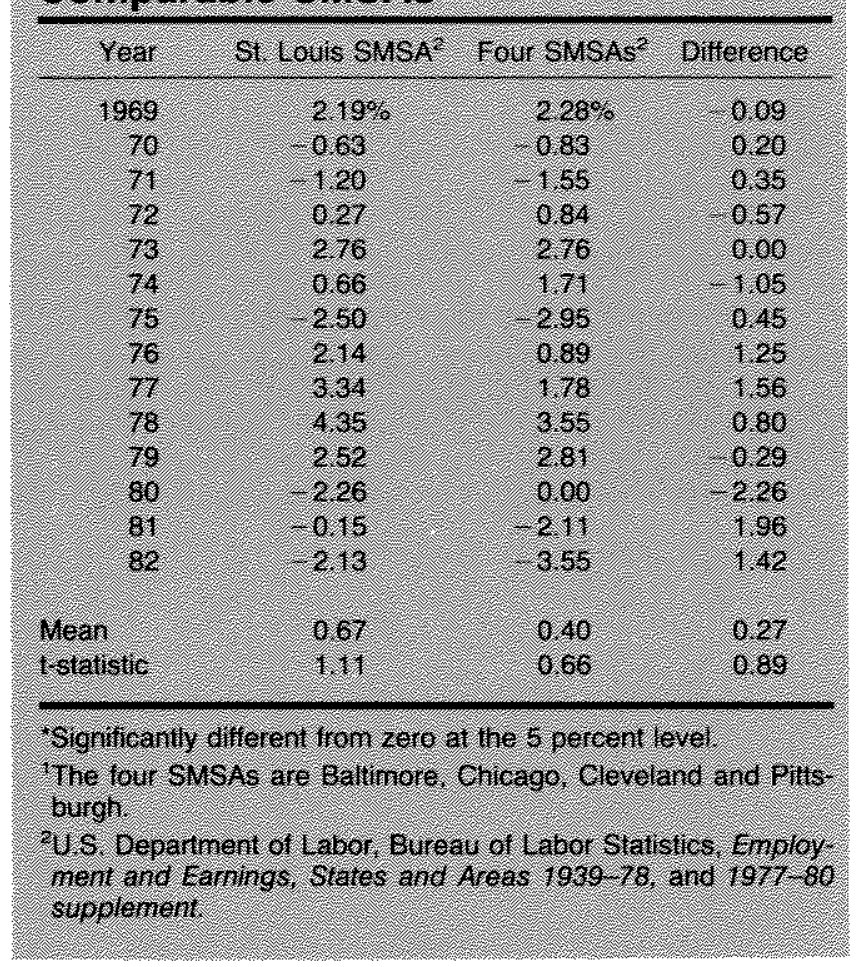

the nation is a phenomenon that has been fairly constant over the past 28 years.

\section{IS THE EMPLOYMENT SITUATION IN ST. LOUIS UNIQUE?}

Although the growth rate in St. Louis employment has been substantially lower than the national growth rate, it is not necessarily lower than employment growth rates in similar metropolitan areas. Table 4 presents the annual growth rates of total nonagricultural employment for St. Louis and the average of four other comparably sized and geographically located SMSAs for the past 14 years. These comparable SMSAs are Baltimore, Chicago, Cleveland and Pittsburgh. ${ }^{11}$

As the last column of the table indicates, the growth rate of employment in St. Louis fluctuates around the

\footnotetext{
${ }^{11}$ The selection was restricted to cities located outside the Sun Belt and of roughly the same size as St. Louis in 1982 .
} 
average employment growth for the four other SMSAs. On average, however, it does not differ significantly from their average growth rates. St, Louis' relatively slow rate of growth in nonagricultural employment, when compared with employment growth in the nation, is not unique; it is shared by other comparable SMSAs.

\section{CONCLUSIONS}

The mix of nonagricultural employment has changed both in the St. Louis SMSA and at the national level since 1954, Employment in manufacturing industries has declined in relative importance while employment by government and in the service industries has increased. Concentration of employment in manufacturing industries was relatively high in the St. Louis area in 1954 but has declined to about the national average. A notable exception is transportation equipment manufacturing. While the percentage of individuals employed in this industry had declined at the national level since 1954, it has increased in St. Louis.

The average rate of employment growth in St. Louis has consistently been lower than the national average since 1954. Once this lower average growth rate is taken into account, it does not appear that recessions have a differentially severe effect on the St. Louis labor market. Finally, relatively slow growth in employment is not unique to St. Louis; other comparable SMSAs display the same pattern.

\section{REFERENCES}

Employment and Eamings, States and Areas 1939-78, and 1977-80 supplement. U.S. Department of Labor, Bureau of Labor Statistics.

Employment and Earnings, United States, 1909-78, and July 1983 supplement. U.S. Department of Labor, Bureau of Labor Statistics.

Gibert, A. Alton. "Employment Growth in St. Louis," this Review (Augusi 1973), pp. 9-15.

"G.M. Plans Second Shift at Wentzville." St. Louis Post-Dispatch, September 20, 1983.

Kester, Bill. "St. Louis Rebound Lags U.S. Economic Recovery," St. Louis Post-Dispatch, September 7, 1983.

Report on Employment. U.S. Department of Labor, Bureau of Labor Statistics.

"Sirong Economic Muscle." St. Louis Globe-Democrat, August 17 , 1983.

"Strong Upward Trend in Hiring." St. Louis Globe-Democrat, September 19, 1983

"The Slow Road to Recovery." St. Louis Post-Dispatch, September $13,1983$.

Wagman, Paul. "Auto Industry in St. Louis Returning to High Gear," Christian Science Monitor, September 26, 1983. 